Research article

\title{
Floristic composition and plant community analysis of vegetation in Ilu Gelan district, West Shewa Zone of Oromia region, Central Ethiopia
}

\author{
Zerihun Tadesse $^{1,2}$, Ensermu Kelbessa ${ }^{1}$ and Tamrat Bekele ${ }^{1}$ \\ ${ }^{1}$ Department of Plant Biology and Biodiversity Management, the National Herbarium, Addis Ababa University, \\ P.O.Box: 3434, Addis Ababa, Ethiopia \\ ${ }^{2}$ Wollega University, Faculty of Agriculture, Department of Plant Science, Shambu, Ethiopia
}

*Corresponding Author: zerihunbio@gmail.com

[Accepted: 26 August 2017]

\begin{abstract}
This study was conducted on Dirki and Jato sites vegetation in Ilu Gelan district, west Shewa zone of Oromia region, $195 \mathrm{~km}$ west of Addis Ababa, to identify floristic composition and plant community types the vegetation. Systematic sampling method was used to collect vegetation data from $54(20 \mathrm{~m} \times 20 \mathrm{~m})$ plots. To collect data for herbaceous plants, five $1 \mathrm{~m} \times 1 \mathrm{~m}$ subplots were laid in each of the main plot, where four were at the corners and one at the center. Cover/abundance values were visually estimated to use for cluster analysis. Shannon - Wiener Diversity Index was used to calculate species diversity, richness and evenness whereas Soresen's Similarity ratio was used to compare the vegetation with other related vegetation. Two hundred and thirteen species were recorded from the sample plots, where Fabaceae, Asteraceae and Poaceae were the most dominant families with 23, 22 and 12 species respectively. Eleven endemic and two near endemic species were recorded from the study area. Based on IUCN Red Data List, nine species were least concern; three were near threatened while one was vulnerable. Three plant community types were recognized from the study area.
\end{abstract}

Keywords: Plant community - Diversity - Endemic species - Near endemic species - Abundance.

[Cite as: Tadesse Z, Kelbessa E \& Bekele T (2017) Floristic composition and plant community analysis of vegetation in Ilu Gelan district, West Shewa Zone of Oromia region, Central Ethiopia. Tropical Plant Research 4(2): 335-350]

\section{INTRODUCTION}

Ethiopia is a country found in the horn of Africa between the geographical coordinates of $3^{\circ} 24^{\prime}$ and $14^{\circ} 53^{\prime}$ North and $32^{\circ} 42^{\prime}$ and $48^{\circ} 12^{\prime}$ East. According to MOA (2000), the total area of the land of the country is 1.12 million $\mathrm{km}^{2}$. The country has different topographic land features such as mountains, deep gorges, low lands, valleys and flattened plateaus. These different topographic features assisted different types of flora and fauna that have been well adapted to their own geographical features and climatic conditions. According to Fayera Senbeta et al. (2007), the climate and topography of Ethiopia vary considerably and appear to have effects on the distribution of biological diversities. Thus, Ethiopia has been considered a country having high biodiversity in Horn of Africa (NBSAP 2005).

A large part of Ethiopia was believed to have been covered by forests and woodland vegetations in the past (Friis 1992). However, due to continuous massive deforestation made on it, the vegetation cover has been reduced through time to what it looks like at the present (Moges et al. 2010). Different researchers have studied the vegetation of Ethiopia at different times (White 1983, Friis 1992, Teketay 1992, Bekele 1994, Ayalew 2003, Awas et al. 2001, Senbeta 2006, Senbeta et. al. 2007, Didita 2007, Adamu et al. 2012, Dibaba et al. 2014). The results of these studies could broadly categorize the vegetations of Ethiopia into nine major types. These include: Afroalpine and Subafroalpine Vegetation, Dry Evergreen Montane Vegetation, Moist Evergreen Montane Forest, Evergreen Scrub, Combretum-Terminalia (broad-leaved deciduous) woodland, AcaciaCommmiphora (Small-leaved deciduous) woodland, Wetlands, Lowland Dry forest, and Desert and semi-Desert 
scrub. Out of the nine vegetation types, four of them occur in the dryland regions. These include,

1) Combretum-Terminalia (Broud-leaved deciduous woodland),

2) Acacia-Commiphora (Small-leaved deciduous woodland),

3) Desert and semi-desert scrub land, and

4) Dry Evergreen Montane Vegetation.

The coverage of each of the vegetation category has been declining rapidly due to the anthropogenic impacts such as demand of land use for expansion of agriculture by local farmers, overgrazing, illegal exploitation of forests and forest products (Friis 1992, Senbeta \& Tefera 2001). Extensive agricultural investment and expansion of road construction through vegetation are also becoming other causes of deforestation. Currently, increasing rate of drought, desertification and shortage of food for both humans and animals are becoming serious problems that need attentions (Moges et al. 2010). These problems are directly related to the pressures exerted on vegetation by human beings, and thus need immediate solutions. Therefore, it is very important to study the current status of our vegetation to identify the problems and threats associated with them and make a useful recommendation that is helpful for planning their future conservation and sustainable management.

The aim of this study was to generate basic scientific information by identifying and documenting the floristic composition and plant community structures of the vegetation in the study area. In addition to this, it aimed to assess and point out the environmental factors influencing the structures of the plant communities.

\section{MATERIALS AND METHODS}

Description of the study area

Ilu Gelan District is found in West Shewa Zone of Oromia Regional State, central Ethiopia (Fig. 1). The District is located on the Addis Ababa-Nekemte main road about $200 \mathrm{~km}$ from Addis Ababa to the west. IJaji is the central town of the District and is located on geographical coordinates of $08^{\circ} 59^{\prime} 51^{\prime \prime} \mathrm{N}$ and $37^{\circ} 19^{\prime} 49^{\prime \prime} \mathrm{E}$ with the altitude of $1812 \mathrm{~m}$ a.s.l.

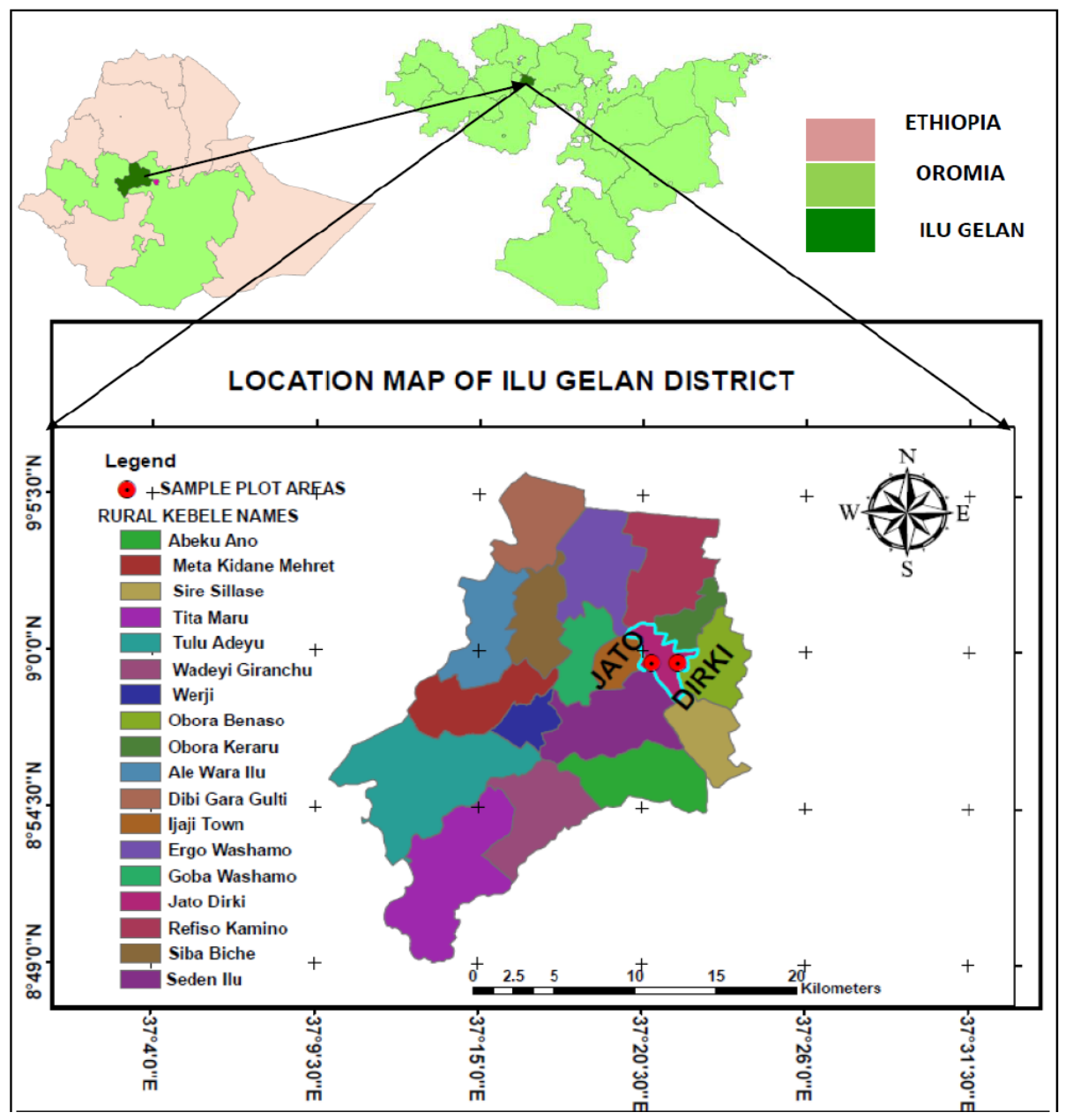

Figure 1. Map of Ethiopia showing the Regional States and the study area. 
This study was conducted in the District on two nearby sites known as Dirki and Jato which are found on the south of the main road when driving from Gedo, the central town of Cheliya District, to Ijaji at about $10 \mathrm{~km}$ from Gedo to the west. The vegetation of Dirki lies on a steep mountain between $08^{\circ} 59^{\prime} 16.1^{\prime \prime}-08^{\circ} 59^{\prime} 50.8^{\prime \prime} \mathrm{N}$ and $37^{\circ} 22^{\prime} 45.50^{\prime \prime}-37^{\circ} 23^{\prime} 15.8^{\prime \prime} \mathrm{E}$ while that of Jato is found between the latitudes $08^{\circ} 58^{\prime} 41.5^{\prime \prime}-08^{\circ} 59^{\prime} 10.8^{\prime \prime} \mathrm{N}$ and longitudes $37^{\circ} 21^{\prime} 59.7^{\prime \prime}-37^{\circ} 22^{\prime} 50.6^{\prime \prime}$ E.

\section{Climate}

The climate of Ilu Gelan District is considered to belong to the Weina Dega and Kolla agro-ecological zones of Ethiopia. As most parts of the District are found in the low land, the mean annual temperature of the area is relatively high (Amenu 2007). Meteorological data obtained from National Meteorology Service Agency (NMSA 2015), indicates that Ilu Gelan area obtains high rainfall between May and September and low rainfall from December to February (Fig. 2). The climadiagram figure shows that the study area is typical of forest vegetation rainfall distribution. This indicates that the woodland vegetation was resulted from cutting effects exerted on the original forest in the past. According to the data, the highest mean annual rainfall of the study area recorded for twenty years (1995-2014) was $1351 \mathrm{~mm}$ and recorded in July whereas the lowest mean annual rainfall was $11.2 \mathrm{~mm}$ and recorded in February. The mean maximum temperature over the twenty years was $28.1^{\circ} \mathrm{C}$ while the mean minimum temperature was $13.8^{\circ} \mathrm{C}$. The highest temperature, $31.7^{\circ} \mathrm{C}$, was recorded in February whereas the lowest temperature, $11.2^{\circ} \mathrm{C}$, was recorded in November.

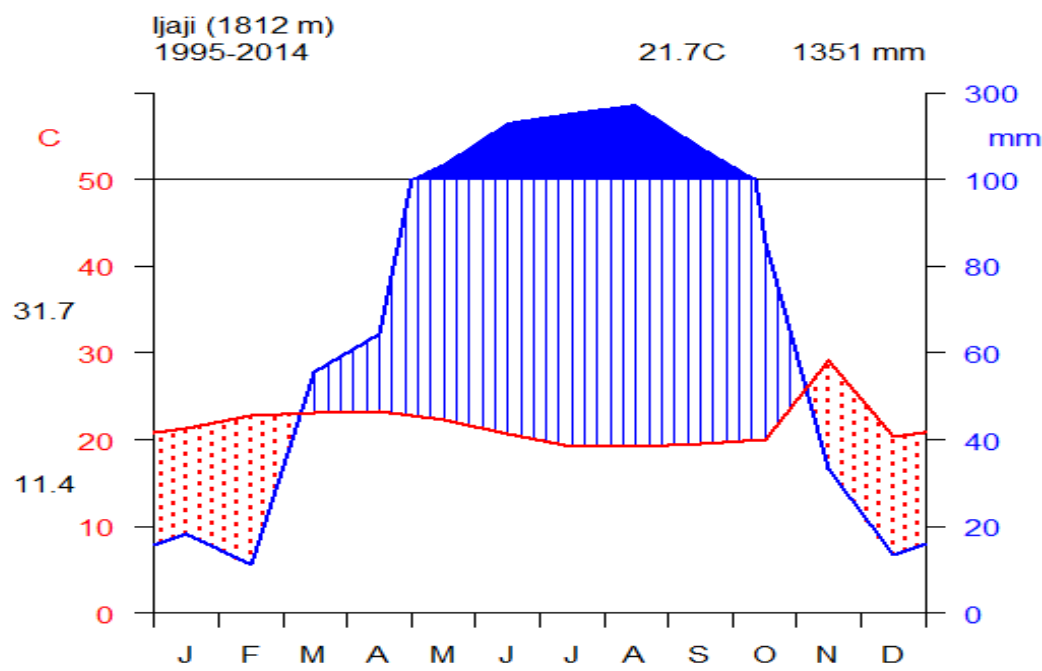

Figure 2. Climadiagram showing rainfall distribution and temperature variation from 1995-2014 around Ijaji Town. [Source: National Meteorological Service Agency (NMSA 2015)]

\section{Sampling design}

Systematic transect sampling following Kent \& Coker (1992) was used for the study. After the highest altitude was recorded, one $20 \mathrm{~m} \times 20 \mathrm{~m}$ quadrat was first taken at the peak of Dirki and radiating transects were laid down from the top to the base of the mountain in four $(\mathrm{N}, \mathrm{W}, \mathrm{S}$ and $\mathrm{E})$ directions. However, in the case of Jato, vegetation cover is found only in the north and north-west facing aspects of extending escarpment. Thus, three transect lines were laid down from the top to the base of the escarpment on the north and north-west facing aspects, where the distance between the three consecutive transects was measured to be $300 \mathrm{~m}$.

Along the transect lines of each study site, $20 \mathrm{~m} \times 20 \mathrm{~m}\left(400 \mathrm{~m}^{2}\right)$ quadrats were laid down at every $25 \mathrm{~m}$ altitudinal drop to analyze species turnover. Each transect contains different numbers of plots depending on the length of each transect. In addition, five $1 \mathrm{~m} \times 1 \mathrm{~m}$ subplots, one at each of the four corners and one at the center of the $20 \mathrm{~m} \times 20 \mathrm{~m}$ main plot were also laid to sample herbaceous plants. A total of fifty four $20 \mathrm{~m} \times 20 \mathrm{~m}$ quadrats were laid for vegetation data collection, where 32 were from Dirki and the rest 22 from Jato site.

\section{Data collection}

a. Environmental data collection:

In each of the quadrat, altitude and geographical coordinates were measured using Garmin 72 GPS (Geographical Position System) and aspect was determined using Suunnto Compass. Codes were given to aspects following Woldu et al. (1989) as:

North $=0 ;$ East $=2 ;$ South $=4$; West $=2.5$ and $\mathrm{NW}=1.3$ 
Ecological disturbances such as grazing and impacts of human beings (cutting, collecting firewood, producing charcoal and trampling in the vegetation) were noticed and recorded as present or absent in the sampled plots. Grazing intensity was estimated following Woldu \& Backeus (1991) and Tekle et al. (1997) as:

$$
0=\text { nil; } 1=\text { slight } 2=\text { moderate and } 3=\text { heavy }
$$

The state of human interference was estimated following Hadera (2000), Yeshitela \& Bekele (2002), Kidane et al. (2010) and codified using a 0-3 subjective scale to record the degree of the impacts (from cutting, fuel wood collection, charcoal production and sign of trampling) as:

$$
0=\text { nil; } 1=\text { low; } 2=\text { moderate and } 3=\text { heavy }
$$

b. Vegetation data collection:

Data collection was conducted from November 06 to 20, 2014. A complete list of trees, shrubs, lianas, and herbs was made from the systematically selected plots laid down along each transect. Plant species that occur outside the sample plots, but inside the study area were recorded as present in the floristic composition to produce a complete list of the plants in the vegetation area. Estimation of cover/abundance values for woody species was made and recorded in the field.

The local name of each species, if present, was recorded during the field work. Specimens of all encountered woody and herbaceous plants were collected, pressed, dried and brought to the National Herbarium (ETH), Addis Ababa University, for taxonomic identification. The specimens were identified by comparing with authenticated specimens housed at ETH and by referring to the Flora of Ethiopia and Eritrea. Voucher specimens were kept at ETH.

Cover abundance data defined here as the proportion of area in a quadrat covered by every species recorded and gathered from each quadrat were converted to the 1-9 Braun-Blanquet scale, which was later modified by van der Maarel (1979).

\section{Data analysis}

a. Vegetation classification:

The computer program $\mathrm{R}$ software for windows 3.0.2 version was used to analyze the vegetation data through Agglomerative Hierarchical Classification technique. Euclidean distance and Ward's method were used for clustering the vegetation data using $\mathrm{R}$ software for windows 3.0.2 version. Three plant community types were obtained from the hierarchical clustering analysis and named using two characteristic species having the highest mean cover abundance values in their community.

b. Diversity analysis:

Shannon-Wiener Diversity Index was used to analyze the species diversity, species richness and evenness of the vegetation as:

$$
\boldsymbol{H}=-\sum \boldsymbol{P i} \ln \boldsymbol{P i}
$$

Where, H: Shannon-Wiener Index; Pi: proportion of individual species; $\ln : \log$ base $_{\mathrm{n}}$.

The equitability or evenness of the species in each quadrat was computed using the formula:

$$
\text { Equitability } J=\frac{H^{\prime}}{H \max }=\sum_{i=1}^{S} \frac{P i \ln P i}{\ln S}
$$

Where, S: the number of species; Pi: the proportion of individuals of the $i^{\text {th }}$ species or the abundance of the $i^{\text {th }}$ species expressed as a proportion of total cover; $\ln$ : log base.

c. Phytogeographical similarity:

Sorenson's Similarity ratio was used to evaluate the similarity between the three plant community types of the vegetation in the study area and as well as the similarity between the Vegetation and four other previously studied vegetationon the basis of their species composition.

$$
S s=\frac{2 a}{2 a+b+c}
$$

Where, Ss: Sorensen's similarity coefficient; a: number of species common to both samples /communities/ study areas; b:number of species in sample 1; c: number of species in sample 2.

\section{RESULTS}

\section{Floristic composition}

The study showed that Dirki and Jato vegetation (Fig. 3 \& Fig. 4) had high species richness in plants of different growth forms. Plant species of different growth forms (trees, shrubs, lianas and herbs) were recorded 
from the study area (Fig. 5). Out of the total plant species recorded from the study area, trees and herbs each comprised $32.71 \%$ while shrubs and lianas constituted $27.57 \%$ and $7.01 \%$ respectively.

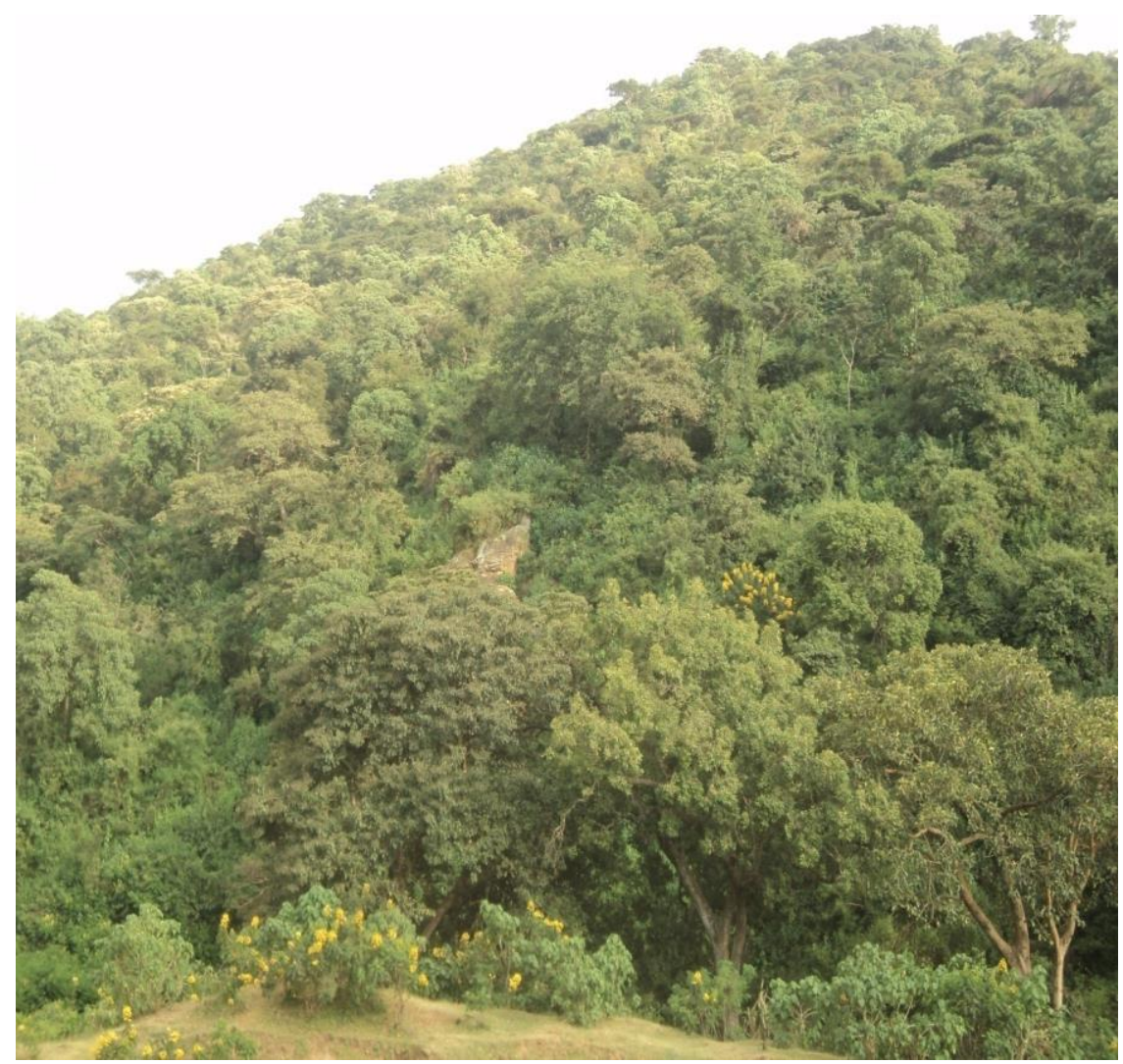

Figure 3. Vegetation of Dirki site.

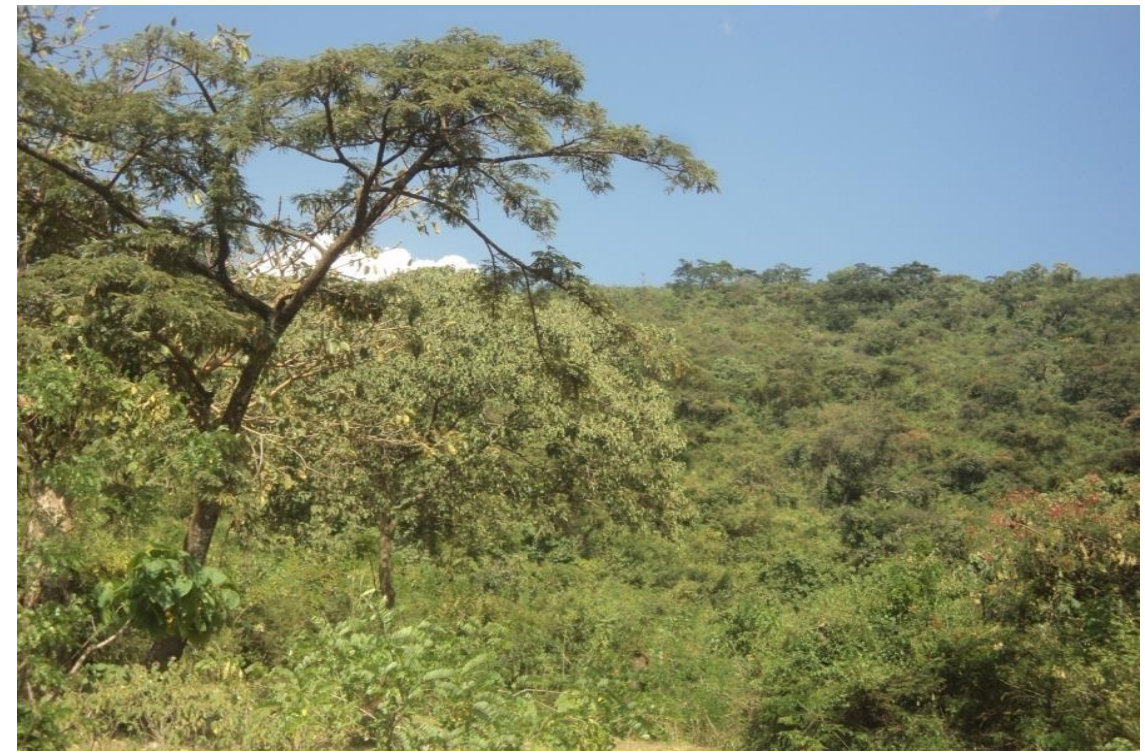

Figure 4. Vegetation of Jato site.

A total of 69 families with 167 genera and 214 species were recorded from the study area (Appendix 1). Of all the families, Fabaceae, Asteraceae and Poaceae were the three most dominant families represented by 18,15 and 11 genera, and 23, 22 and 12 species respectively. These three dominant families together constituted 57 (26.64\%) of the total species richness in Dirki and Jato Vegetation. The next dominant families, Euphorbiaceae, Acanthaceae, Rubiaceae, Lamiaceae and Combretaceae were represented by 11, 9, 9, 9 and 7 species respectively and constituted $45(21.03 \%)$ of the total species. Other four families which accounted $23(10.75 \%)$ of the total species were Malvaceae, Moraceae and Rhamnaceae and constituted six species each, while Solanaceae was represented by five 5 species. 

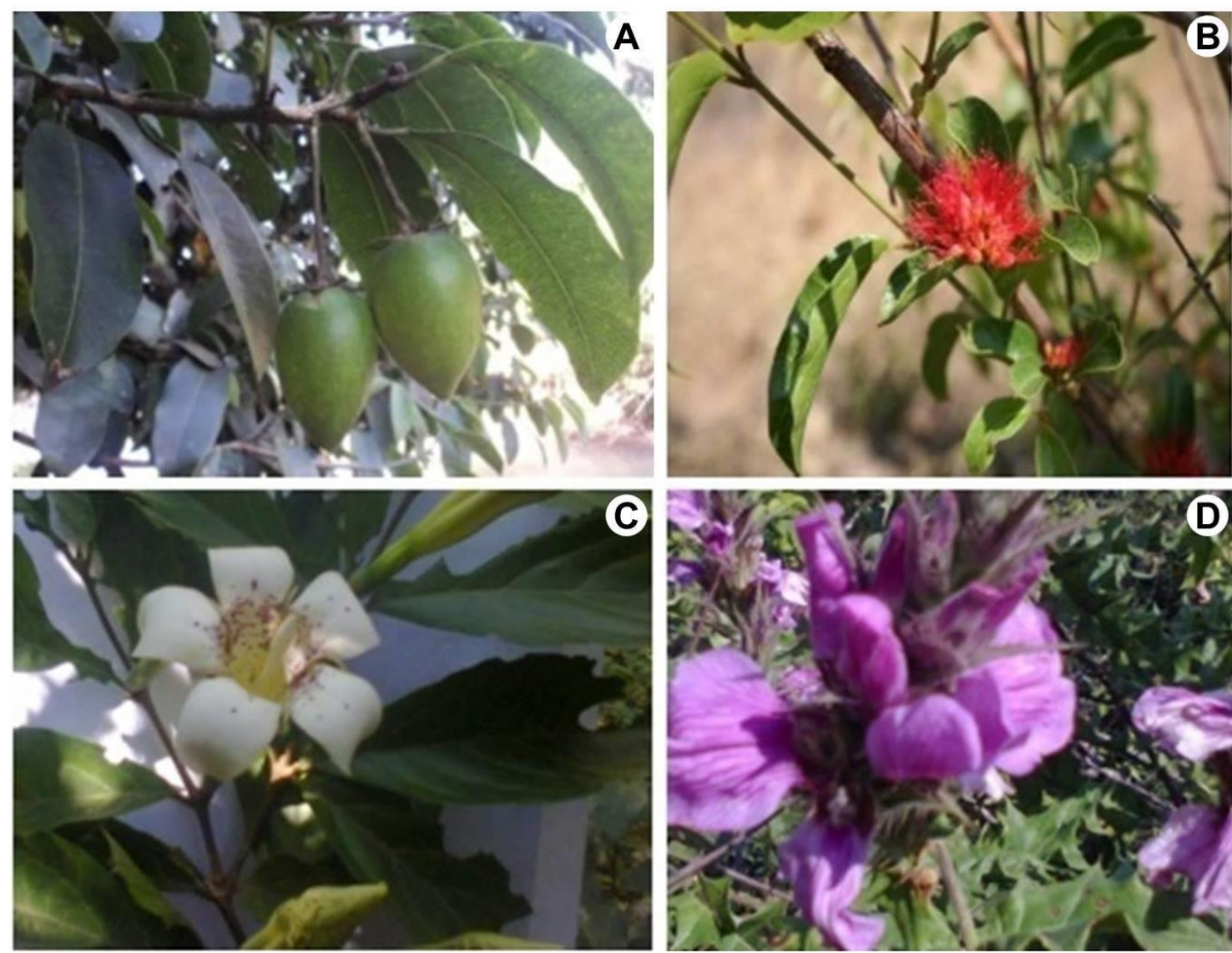

Figure 5. Some of the collected plants from the study area: A, Mimusops kummel A. DC.; B, Combretum paniculatum Vent.; C, Rothmannia urcelliformis (Hiem) Robyns; D, Acanthus polystachius Delile.

Each of the families Oleaceae, Ranunculaceae and Rosaceae were represented by four species while Boraginaceae, Celastraceae, Loganiaceae, Sapindaceae and Verbenaceae were represented by three species each. These eight families constituted 27 (12.62\%) species while other 13 families represented by 2 species each constituted $26(12.15 \%)$ of the total species. The rest 36 families that contributed $16.82 \%$ of the total species were represented by one species each. Out of the total 214 species identified from the study area, one hundred and six, which were collected from the 54 quadrats were used in the floristic analysis. The rest 108 plant species were collected from outside of the quadrats but inside the woodland vegetation, and included in the floristic list to make the description of the vegetation more reliable.

Endemic plant species

Table 1. List of endemic species with their IUCN threat categories

\begin{tabular}{llll}
\hline Species & Family & Habit & IUCN category \\
\hline Acanthus sennii Chiov. & Acanthaceae & S & NT \\
Bidens ghedoensis Mesfin & Asteraceae & H & LC \\
Bidens pachyloma (Oliv. \& Hiern) Cufod. & Asteraceae & H & LC \\
Cirsium schimperi (Valke) C. Jeffrey ex Cufod. & Asteraceae & H & LC \\
Clematis longicauda Steud.ex A. Rich. & Ranunculaceae & L & LC \\
Crotalaria rosenii (Pax) Milne-Redh.ex Polhill & Fabaceae & H & NT \\
Echinops longisetus A. Rich. & Asteraceae & H & LC \\
Lippia adoensis Hochst. ex Walp & Verbenaceae & S & LC \\
Millettia ferruginea (Hochst.) Bak. & Fabaceae & T & NT \\
Phyllanthus mooneyi M. Gilbert & Euphorbiaceae & S & VU \\
Pycnostachys abyssinica Fresen. & Lamiaceae & H & LC \\
Solanum marginatum L.f. & Solanaceae & S & LC \\
Vernonia leopoldi (Sch. Bip. ex Walp.) Vatke & Asteraceae & S & LC \\
\hline
\end{tabular}

Note: $\mathrm{T}=$ Tree, $\mathrm{S}=$ Shrub, L= Liana, H= Herb; NT= Near Threatened, LC= Least Concern, VU= Vulnerable.

Out of the total plant species identified from the study area, eleven species were identified as endemic to Ethiopia while two were near endemic i.e., confined to Ethiopia and Eritrea (Table 1). Based on the IUCN www.tropicalplantresearch.com 
Criteria of level of threat, nine species were least concern (LC), three species were assessed as near threatened (NT) while one species was vulnerable (VU).

\section{Vegetation classification}

a. Plant community types:

Three plant community types were identified from the hierarchical cluster analysis using the computer software program $\mathrm{R}$ for windows version 3.0.2. The computer program for determining the optimal number of clusters was used to decide the number of plant community types. Ward's method and Euclidean distance were used to draw the dendrogram showing dissimilarity among the three clusters (Fig. 6). The vegetation classification was done by using the cover abundance value estimate of each species included in the analysis. Distribution of the three plant community types $\left(\mathrm{C}_{1}=\right.$ Community Type $1, \mathrm{C}_{2}=$ Community Type 2 , and $\mathrm{C}_{3}=$ Community Type 3) along with their altitudinal range was given in table 2 . The plant community types were named by two characteristic species confied to only one of the three plant community types (Table 3 ).

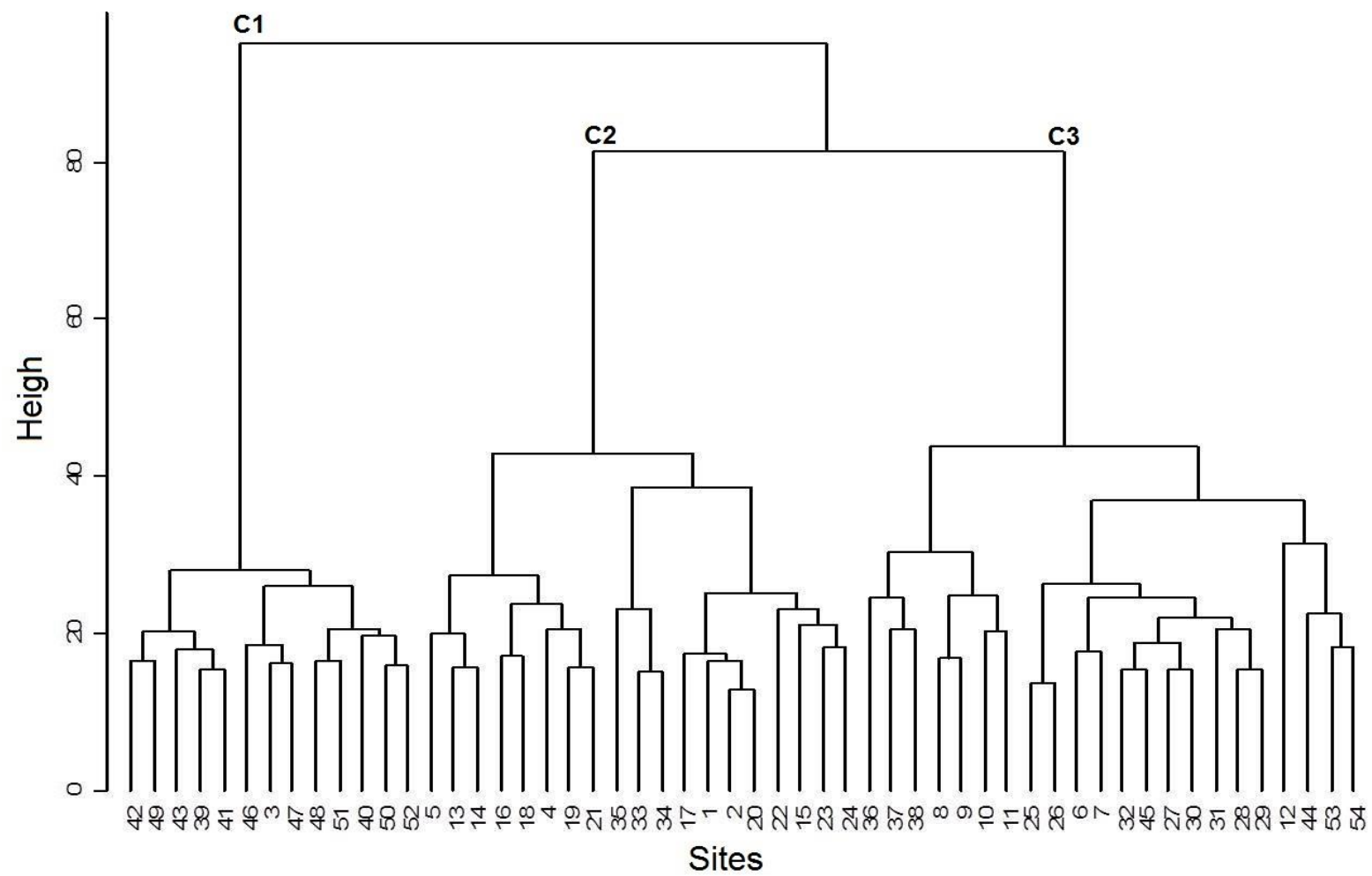

Figure 6. Dendrogram showing the plant community types of the study area. [Agglomerativ Hierarchical Clustering Using Euclidean Distance equation: $\sqrt{\sum(\mathrm{X} i \mathrm{j}-\mathrm{Xik})^{2}}$ ]

Table 2. Distribution of plots of the three plant communities with their altitudinal ranges.

\begin{tabular}{|c|c|c|c|}
\hline Community & Altitude (m a.s.l.) & Total plots & List of plots \\
\hline $\mathrm{C} 1$ & $1920-2136$ & 13 & $3,39,40,41,42,43,46,47,48,49,50,51$ and 52 \\
\hline $\mathrm{C} 2$ & $1950-2078$ & 19 & $\begin{array}{l}1,2,4,5,13,14,15,16,17,18,19,20,21,22,23,24,33, \\
34 \text { and } 35\end{array}$ \\
\hline $\mathrm{C} 3$ & $1803-1953$ & 22 & $\begin{array}{l}6,7,8,9,10,11,12,25,26,27,28,29,30,31,32,36,37, \\
38,44,45,53 \text { and } 54\end{array}$ \\
\hline
\end{tabular}

Descriptions of the three plant community types

a. Acacia etbaica - Lantana trifolia community type

This community type is distributed between the altitudinal range of 1920-2136 m a.s.l. It is represented by 13 plots comprising 62 plant species; out of which 50 are commonly shared with community two and 51 with community three. Acacia etbaica and Lantana trifolia are the characteristic species of this community. Acacia abyssinica is a dominant tree species in this community type while other common tree and shrub species associated with the community include: Maesa lanceolata, Syzygium guineense, Combretum molle, Premna schimperi, Hypericum quartinianum, Rosa abyssinica, Stereospermum kunthianum and Nuxia congesta. In this www.tropicalplantresearch.com 
community, common herbaceous species covering the ground surface are Bidens biternata, Bidens ghedoensis, Cynodon dactylon and Oplismenus hirtellus.

b. Buddleja polystachya - Teclea nobilis community type

This community is distributed between the altitudinal range of 1950-2078 m a.s.l. It is represented by 19 plots consisting of 73 species; out of which 50 are shared with community one while 66 species are shared with community three. Buddleja polystachya and Teclea nobilis are the characteristic species in the community. Calpurnia aurea is a dominant species whereas common tree and shrub plant species found in this community include Osyris quadripartita, Albizia schimperiana, Rhus natalensis, Euclea divinorum, Olinia rochetiana and Schrebera alata. Whereas, Helinus mystacinun and Dioscorea shimperiana are common lianas recorded in this community type. On the other hand, Hypoestes aristata, Panicum monticola, Justicia ladanoides and Cyperus sesquiflorus are the dominant species at herbaceous level.

c. Combretum paniculatum - Rothmannia urcelliformis community type

This community type is distributed between the altitudinal range of $1803-2080 \mathrm{~m}$ a.s.1. It is represented by 22 plots consisting of 95 species. Combretum paniculatum and Rothmannia urcelliformis are characteristic species of the community. Other dominant woody species of this community include: Clausena anisata, Maytenus arbutifolia, Grewia ferruginea, Calpurnia aurea, Carissa spinarum, Croton macrostachyus, Millettia ferruginea, Acacia abyssinica, Bersama abyssinica, Vangueria apiculata and Rytigynia neglecta. On the Other hand, Clematis longicauda is a characteristic liana of this community whereas the characteristic herbaceous species covering the ground surface are Achyranthes aspera, Cynodon nlemfuensis, Pycnostachys abyssinica and Setaria megaphylla.

Table 3. Mean cover abundance estimates of species of the three communities.

\begin{tabular}{lllr}
\hline & \multicolumn{3}{c}{ Community type } \\
\cline { 2 - 4 } Species & One & Two & Three \\
\hline Acacia abyssinica & 4.15 & 2.21 & 3.59 \\
Acacia etbaica & $\mathbf{0 . 0 8}$ & 0.00 & 0.00 \\
Albizia schimperiana & 2.69 & 6.00 & 2.55 \\
Bersama abyssinica & 1.08 & 5.26 & 3.55 \\
Buddleja polystachya & 0.00 & $\mathbf{0 . 1 1}$ & 0.00 \\
Calpurnia aurea & 4.46 & 7.37 & 5.27 \\
Carissa spinarum & 2.92 & 6.00 & 4.5 \\
Clausena anisata & 2.08 & 7.05 & 6.59 \\
Combretum molle & 3.62 & 2.26 & 1.91 \\
Combretum paniculatum & 0.00 & 0.00 & $\mathbf{1 . 0 9}$ \\
Croton macrostachyus & 4.23 & 5.00 & 4.41 \\
Euclea divinorum & 0.08 & 5.16 & 0.36 \\
Ficus sycomorus & 0.00 & 0.00 & 0.23 \\
Ficus vasta & 0.00 & 0.00 & 0.09 \\
Grewia ferruginea & 3.92 & 4.47 & 5.59 \\
Lantana trifolia & $\mathbf{0 . 0 8}$ & 0.00 & 0.00 \\
Mimusops kummel & 0.00 & 0.00 & 0.23 \\
Olea capensis & 0.00 & 0.00 & 0.31 \\
Olinia rochetiana & 1.85 & 5.26 & 0.05 \\
Osyris quadripartita & 6.23 & 3.53 & 0.55 \\
Premna schimperi & 6.62 & 6.79 & 5.27 \\
Rothmannia urcelliformis & 0.00 & 0.00 & $\mathbf{0 . 3 2}$ \\
Schrebera alata & 0.38 & 3.94 & 0.05 \\
Syzygium guineense & 7.38 & 3.16 & 1.68 \\
Teclea nobilis & 0.00 & $\mathbf{0 . 2 6}$ & 0.00 \\
\hline & & &
\end{tabular}

Species richness, evenness and diversity of the three communities

Shannon-Wiener diversity index was computed for the three plant community types of the woodland vegetation of Ilu Gelan District (Table 4). Community three had the highest diversity followed by community two while community one showed the least diversity. Community type three had the highest species richness whereas the least species rich community is community type one. However, equitability (evenness) which measures the relative abundance of different species present in each community showed relatively the highest value for community two followed by community three and the lowest for community one. 
Tadesse et al. (2017) 4(2): 335-350

Table 4. Shannon-Wiener diversity index for woodland vegetation of Ilu Gelan District.

\begin{tabular}{lrrrrr}
\hline $\begin{array}{l}\text { Community } \\
\text { type }\end{array}$ & $\begin{array}{r}\text { Diversity } \\
\text { index (H') }\end{array}$ & $\begin{array}{r}\text { Species } \\
\text { richness (S) }\end{array}$ & $\mathbf{H}_{\text {max }}$ & $\begin{array}{r}\text { Equitability } \\
(\mathbf{J})\end{array}$ & $\begin{array}{r}\text { Average altitude } \\
(\mathbf{m} \text { a.s.l.) }\end{array}$ \\
\hline One & 3.847 & 62 & 4.128 & 0.932 & 2045.50 \\
Two & 4.068 & 73 & 4.291 & 0.948 & 2014.00 \\
Three & 4.316 & 95 & 4.553 & 0.947 & 1941.50 \\
\hline
\end{tabular}

Similarity between the three plant community types

Sorensen's Coefficient Index was used to calculate the degree of similarity among the three plant community types. The highest similarity was observed between communities one and three while the least similarity was observed between communities two and three. The result from the analysis showed communities one and two, community one and three, and communities two and three shared about $74.63 \%, 64.97 \%$ and $78.57 \%$ similarity in species composition respectively.

\section{DISCUSSION}

Dominance of Fabaceae and Asteraceae has been reported from different floristic studies done by different researchers at different times (Yineger et al. 2008, Tadesse et al. 2008, Abdena 2010, Kebede 2010, Didita et al. 2010, Alemu 2011, Adamu et al. 2012, Dibaba et al. 2014). Similarly, the results from analyzed data showed that Fabaceae and Asteraceae are the most dominant species in Dirki and Jato Woodland Vegetation. Fabaceae and Asteraceae are represented by 23 and 22 species respectively, while Poaceae followed by 12 species. The dominance of these families is also in line with the assessment results that show their dominance positions in the Flora of Ethiopia and Eritrea. Fabaceae and Asteraceae might have got the top dominant position probably due to having efficient pollination and successful seed dispersal mechanisms that might have adapted them to a wide range of ecological conditions in the past (Kelbessa \& Soromessa 2008). However, the variation in topography and environmental conditions like the amount of rainfall and temperature could be the causes of variation in dominance positions of plants taxa. Ethiopia is considered one of the countries of east Africa known by plant endemism (Vivero et al. 2005). The diverse topographic land features having various climatic conditions assisted Ethiopia to be a country of high biodiversity (Gebrehiwot \& Hundera 2014).

Results from data analysis showed that the woodland vegetation of Dirki and Jato consists of 13 endemic species of the flora of Ethiopia and Eritrea. From these, 11 species are endemic to Ethiopia while two are near endemic (Lippia adoensis and Solanum marginatum are confined to Ethiopia and Eritrea). Based on the IUCN Criteria of the level of threat, nine species are least concern (LC); three species are near threatened (NT) while one species has been categorized under vulnerable (VU).

\section{Plant community types}

The results from cluster analysis showed that there are differences among the three plant communities in species composition. The differences could be attributed to variations in environmental gradients that can limit the ecological distributions of plant species (Lulekal 2014). As described in Bekele (1993), this variation in species composition could also be related to the effects of environmental factors such as altitude, aspect, soil contents and moisture, human impacts and grazing intensity. Lower altitudinal ranges, aspects more exposed to sun light directions, soils with sufficient moisture contents and part of vegetation less exposed to disturbance accesses can support relatively more biodiversity than the reverse of each component.

\section{CONCLUSION}

The results from this study showed that plant species of different life forms (trees, shrubs, lianas and herbs) were identified from the vegetation of Dirki and Jato in Ilu Gelan District. Out of the total plant species recorded from the vegetation, most proportions $(65.42 \%)$ were trees and herbs while the rest $27.57 \%$ and $7.01 \%$ were shrubs and lianas respectively.

Plants recorded from the study area belong to 69 families, 167 genera and 214 species; whereas Fabaceae, Asteraceae and Poaceae were the most dominant families with 23, 22 and 12 species respectively. These three dominant families constituted $26.64 \%$ of the total species richness of the study area. Euphorbiaceae and Acanthaceae were the fourth and fifth dominating families while Rubiaceae, Lamiaceae and Combretaceae were the next three consecutive dominant families in the vegetation. These five species are represented by $11,9,9,9$ and 7 species respectively, and constitute $45(21.03 \%)$ of the total species recorded from the study area. Families Malvaceae, Moraceae, Rhamnaceae and Solanaceae constitute 23 (10.75\%) of the total species and the 
first three families were represented by six species each while Solanaceae contributed five species. Families Oleaceae, Ranunculaceae and Rosaceae were represented by four species each while families represented by three species each in the vegetation were Boraginaceae, Celastraceae, Loganiaceae, Sapindaceae and Verbenaceae. These eight families together contribute $27(12.62 \%)$ of the total species while other 13 families represented by two species each constituted $26(12.15 \%)$ of the total species. The rest $36(16.82 \%)$ families were represented by only one species each.

Of the total 214 species identified from the study area, 11 are endemic to Ethiopia while two species are near endemic (Lippia adoensis and Solanum marginatum are found in Ethiopia and Eritrea only). According to the IUCN Red Data List, nine of these species were included in least concern (LC), two were considered near threatened (NT) whereas one species has been put under vulnerable (VU) category.

Based on the cover abundance values of the identified species, three plant community types were recognized from the study area and named by two characteristic species having highest mean cover abundance estimate in each community. The three communities are Acacia etbaica - Lantana trifolia Community Type, Buddleja polystachya - Teclea nobilis Community Type and Combretum paniculatum - Rothmannia urcelliformis Community Type. Community three had the highest diversity and species richness than the two communities. Communities one and two were more similar in species composition than communities one and three or two and three.

\section{ACKNOWLEDGEMENTS}

The authors express their grateful acknowledge to Cheliya and Ilu Gelan districts for facilitating the necessary conditions needed for the study. They also express their thanks to Addis Ababa University for providing financial supports. Finally, they acknowledge the National Meteorology Service Agency (NMSA) and Central Statistical Agency (CSA) for providing secondary data.

\section{REFERENCES}

Abdena F (2010) Floristic Composition and Structure of Chato Natural Forest in Horo Guduru Wollega Zone of Oromia Region, west Ethiopia, Ph.D. Thesis. Addis Ababa University, Addis Ababa, Ethiopia.

Adamu H, Bekele T \& Dalle G (2012) Plant community and ecological analysis of woodland vegetation in Metema Area, Amhara National Regional State, Northwestern Ethiopia. Journal of Forestry Research 23(4): 599-607.

Alemu S (2011) Woody Species Composition, Diversity and Structural Analysis of Angada Forest in Merti Wereda, Arsi Zone of Oromia Region, Ethiopia. Thesis, Addis Ababa University, Addis Ababa, Ethiopia, Ph.D. Thesis. Addis Ababa University, Addis Ababa, Ethiopia.

Amenu E (2007) Use and Management of Medicinal Plants by Indigenous People of Ejaji area (Cheliya Woreda) West Shoa, Ethiopia: An ethnobotanical approach, Ph.D. Thesis. Addis Ababa University, Addis Ababa, Ethiopia.

Awas T, Bekele T \& Demissew S (2001) An ecological study of the vegetation of Gambella Region, southwestern Ethiopia. SINET: Ethiopian Journal of Science 24(2): 213-228.

Ayalew A (2003) A floristic composition and structural Analysis of Denkoro Forest, south Wello, northern Ethiopia, Ph.D. Thesis. Addis Ababa University, Addis Ababa, Ethiopia.

Bekele T (1993) Vegetation ecology of remnant Afromontane forests on the Central Plateau of Shewa, Ethiopia. Uppsala, Sweden.

Bekele T (1994) Phytosociology and ecology of a humid Afromontane forest on the central plateau of Ethiopia. Journal of Vegetation Science 5: 87-98.

Dibaba A, Soromessa T, Kelbessa E \& Tilahun A (2014) Diversity, Structure and Regeneration Status of the Woodland and Riverine Vegetation of Sire Beggo in Gololcha District, Eastern Ethiopia. Momona Ethiopian Journal of Science 6(1): 7-96.

Didita M (2007) Floristic Analysis of the Woodland Vegetation Around Dello Menna, Southeast Ethiopia, Ph.D. Thesis. Addis Ababa University, Addis Ababa, Ethiopia.

Didita M (2010) Floristic and structural analysis of the woodland vegetation around Dello Menna, Southeast Ethiopia. Journal of Forestry Research 21(4): 395-408.

Friis I (1992) Forest and Forest Trees of Northeast Tropical Africa: Their natural habitats and distribution pattern in Ethiopia, Djibouti and Somalia. Kew Bulletin Additional Series 15: 396. 
Gebrehiwot K \& Hundera K(2014) Species composition, Plant Community structure and Natural regeneration status of Belete Moist Evergreen Montane Forest, Oromia Regional state, Southwestern Ethiopia. Momona Ethiopian Journal of Science 6(1): 97-101.

Hadera G (2000) A study on the ecology and management of the Dessa forest in the northeastern escarpment of Ethiopia, Ph.D. Thesis. Addis Ababa University, Addis Ababa, Ethiopia.

Kebede B (2010) Floristic Composition and Structural Analysis of Gedo Dry Evergreen Montane Forest, West Shewa Zone of Oromia National Regional State, Central Ethiopia. Star Journal 3(2): 119-134.

Kelbessa E \& Soromessa T (2008) Interfaces of Regeneration, Structure, Diversity and Uses of Some Plant Species in Bonga Forest: A reservoir for Wild Coffee Gene Pool. SINET: Ethiopian Journal of Science 31(2): 121-134.

Kent M \& Coker P (1992) Vegetation Description and Analysis: A practical approach. John Wiley and Sons, New York, 363 p.

Kidane L, Bekele T \& Nemomissa S (2010) Vegetation Composition in Hugumbirda-Gratkhassu National Forest Priority Area, South Tigray. Momona Ethiopian Journal of Science 2(2): 27-48.

Lulekal E (2014) Plant Diversity and Ethnobotanical Study of Medicinal Plants in Ankober District, North Shewa Zone of Amhara Region, Ethiopia, Ph.D. Dissertation. Addis Ababa University, Ethiopia.

Moges Y, Eshetu Z \& Nune S (2010) Ethiopian forest resources: Current status and future management options In View of Access to Carbon Finances. Ethiopian Climate Research and Networking with The United Nations Development Programme (UNDP), Addis Ababa, Ethiopia.

NBSAP (2005) National Biodiversity Strategy and Action Plan. Addis Ababa, Ethiopia.

NMSA (2015) Data of Rainfall and Temperature of twenty years (1995-2014) of Ijaji area. National Metrological Service Agency. Ethiopia.

Senbeta F \& Tefera F (2001) Environmental Crises in the Abiyata-Shalla Lakes National Park. In: Imperative Problems Associated with Forestry in Ethiopia. XI ${ }^{\text {th }}$ Annual Conference of Biological Society of Ethiopia, February 1-2, 2001, Faculty of Science, Addis Ababa University.

Senbeta F (2006) Biodiversity and Ecology of Afromontane Rainforests with Wild Coffea arabica L. Populations in Ethiopia. Ecology and Development Series No. 38. Center for Development Research, University of Bonn.

Senbeta F, Woldemariam T, Demissew S \& Denich M (2007) Floristic Diversity and Composition of Sheko Forest, Southwest Ethiopia. Ethiopian Journal of Biological Sciences 6(1): 11-42.

Tadesse G, Bekele T \& Demissew S (2008) Dryland woody vegetation along an altitudeinal gradhient on the eastern escarpment of Wello. SINET: Ethiopian Journal of Science 31(1): 543-591.

Teketay D (1992) Human Impact on a Natural Montane Forest in southern Ethiopia. Mountain Research and Development 12: 393-400.

Tekle K, Backeus I, Skuglund J \& Woldu Z (1997) Vegetation on hillslopes of Wello, Ethiopia: Degradation and regeneration. Nordic Journal of Botany 17(5): 483-493.

van der Maarel E (1979) Transformation of cover-abundance values in phytosociology and its effects on community similarity. Vegetation 39: 97-114.

Vivero JL, Kelbessa E \& Demissew S (2005) The Red List of Endemic Tree and Shrubs of Ethiopia and Eritrea. Fauna Flora International, Cambridge, UK.

White F (1983) The Vegetation of Africa. UNESCO, Switzerland.

Woldu Z \& Backeus I (1991) The shrub land vegetation in Western Shewa, Ethiopia and its possible recovery. Journal of Vegetation Science 2: 173-180.

Woldu Z, Feoli E \& Nigatu L (1989) Partitioning an elevation gradient of vegetation from southeastern Ethiopia by probabilistic methods. Vegetatio 81: 189-198.

Yeshitela K \& Bekele T (2002) Plant community analysis and ecology of Afromontane transitional rainforest vegetation of southern Ethiopia. SINET: Ethiopian Journal of Science 25(2): 155-175.

Yineger H, Kelbessa E, Bekele T \& Lulekal E (2008) Floristic Composition and Structure of the Dry Afromontane Forest at Bale Mountains National Park, Ethiopia. SINET: Ethiopian Journal of Science 31(2): 103-120. 
Appendix 1. List of plant species collected from Dirki and Jato sites in Ilu Gelan District.

\begin{tabular}{|c|c|c|c|c|c|c|}
\hline S.N. & Species name & Family & Local name & Ha & C. code & Housed at \\
\hline 1 & Abutilon longicuspe Hoehst. ex A. Rich. & Malvaceae & Hincinnii & S & Z192 & ETH \\
\hline 2 & Acacia abyssinica Hochst. ex Benth. & Fabaceae & Laaftoo & $\mathrm{T}$ & Z023 & ETH \\
\hline 3 & Acacia etbaica Schweinf. & Fabaceae & Doddota & $\mathrm{T}$ & Z197 & ETH \\
\hline 4 & Acacia persiciflora $\mathrm{Pax}$ & Fabaceae & Laaftoo & $\mathrm{T}$ & Z204 & ETH \\
\hline 5 & Acanthus polystachius Delile & Acanthaceae & Sokorruu adii & $\mathrm{S}$ & Z176 & ETH \\
\hline 6 & Acanthus sennii Chiov. & Acanthaceae & Sokorruu & $S$ & Z013 & ETH \\
\hline 7 & Achyranthes aspera L. & Amaranthaceae & Maxxannee & $\mathrm{H}$ & Z118 & ETH \\
\hline 8 & Acmella caulirhiza Del. & Asteraceae & & $\mathrm{H}$ & Z182 & ETH \\
\hline 9 & Adiantum poiretii Wikstr. & Adiantaceae & & $\mathrm{H}$ & Z027 & ETH \\
\hline 10 & Albizia schimperiana Oliv. & Fabaceae & Imalaa & $\mathrm{T}$ & Z005 & ETH \\
\hline 11 & Allophylus macrobotrys Gilg & Sapindaceae & Sarara & $\mathrm{T}$ & $\mathrm{Z} 125$ & ETH \\
\hline 12 & Allophylus africanus P. Beauv. & Sapindaceae & Qarxammee & $\mathrm{T}$ & $\mathrm{Z16}$ & ETH \\
\hline 13 & Aloe macrocarpa Tod. & Aloaceae & Hargisa & $S$ & $\mathrm{Z} 178$ & ETH \\
\hline 14 & Andropogon abyssinicus Fresen. & Poaceae & Baallammii & $\mathrm{H}$ & $\mathrm{Z} 179$ & ETH \\
\hline 15 & Apodytes dimidiata E. Mey. ex Am. & Icacinaceae & Qumbaala & $\mathrm{T}$ & Z157 & ETH \\
\hline 16 & Argyrolobium fischeri Taub. & Fabaceae & & $\mathrm{H}$ & Z016 & ETH \\
\hline 17 & Aspilia mossambicensis (Oliv.) Wild & Asteraceae & Keelloo & $\mathrm{S}$ & $\mathrm{Z165}$ & ETH \\
\hline 18 & Asystasia mysorensis (Roth) T. Anders. & Acanthaceae & & $\mathrm{H}$ & Z166 & ETH \\
\hline 19 & Bersama abyssinica Fresen. & Melianthaceae & Lolchiisaa & $\mathrm{T}$ & Z008 & ETH \\
\hline 20 & Bidens biternata (Lour.) Merr. \& Sherfft. & Asteraceae & Keelloo & $\mathrm{H}$ & $\mathrm{Z} 183$ & ETH \\
\hline 21 & Bidens ghedoensis Mesfin & Asteraceae & Keelloo & $\mathrm{H}$ & $\mathrm{Z} 120$ & ETH \\
\hline 22 & $\begin{array}{l}\text { Bidens pachyloma (Oliv. \& Hiern) } \\
\text { Cufod. }\end{array}$ & Asteraceae & Keelloo & $\mathrm{H}$ & $\mathrm{Z} 153$ & ETH \\
\hline 23 & Bridelia micrantha (Hochst.) Baill. & Euphorbiaceae & Agiraabaa & $\mathrm{T}$ & Z094 & ETH \\
\hline 24 & Brucea antidysenterica J.F.Mill. & Simaroubaceae & Qomonyoo & S & $\mathrm{Z} 185$ & ETH \\
\hline 25 & Buddelja davidii Franch. & Loganiaceae & Qawwwisa & $\mathrm{S}$ & Z151 & ETH \\
\hline 26 & Buddleja polystachya Fresen. & Loganiaceae & Qawwisa & $\mathrm{T}$ & Z075 & ETH \\
\hline 27 & Caesalpinia decapetala (Roth) Alston & Fabaceae & Arangamaa & $\mathrm{L}$ & Z149 & ETH \\
\hline 28 & Calpurnia aurea (Ait.) Benth. & Fabaceae & Ceekaa & $S$ & Z001 & ETH \\
\hline 29 & Capparis tomentosa Lam. & Capparidaceae & Arangamaa & $\mathrm{S}$ & $\mathrm{Z} 142$ & ETH \\
\hline 30 & Carissa spinarum $\mathrm{L}$. & Apocynaceae & Agamsa & $\mathrm{S}$ & Z051 & ETH \\
\hline 31 & Celtis africana Burm.f. & Ulmaceae & Cayii & $\mathrm{T}$ & Z108 & ETH \\
\hline 32 & $\begin{array}{l}\text { Chionanthus mildbraedii (Gilg \& } \\
\text { Schellenb.) Stearn }\end{array}$ & Oleaceae & Karra waayyuu & $\mathrm{T}$ & Z199 & ETH \\
\hline 33 & $\begin{array}{l}\text { Cirsium schimper (Valke) C. Jeffrey ex } \\
\text { Cufod. }\end{array}$ & Asteraceae & & $\mathrm{H}$ & $\mathrm{Z} 152$ & ETH \\
\hline 34 & Cissampelos pareira $\mathrm{L}$. & Menispermaceae & Hidda kalaalaa & $\mathrm{L}$ & Z018 & ETH \\
\hline 35 & Clausena anisata (Willd). Benth. & Rutaceae & Ulmaayii & $\mathrm{S}$ & Z003 & ETH \\
\hline 36 & Clematis hirsuta Perr. \& Guill. & Ranunculaceae & & $\mathrm{L}$ & $\mathrm{Z} 144$ & ETH \\
\hline 37 & Clematis longicauda Steud.ex A. Rich. & Ranunculaceae & Hidda fiitii & $\mathrm{L}$ & Z063 & ETH \\
\hline 38 & Clematis simensis Fresen. & Ranunuclaceae & Hidda fiitii & $\mathrm{L}$ & Z020 & ETH \\
\hline 39 & $\begin{array}{l}\text { Clerodendrum myricoides (Hochst.) } \\
\text { Vatke }\end{array}$ & Lamiaceae & & $S$ & $\mathrm{Z} 131$ & ETH \\
\hline 40 & Clutia abyssinica Jaub. \&- Spach. & Euphorbiaceae & & $S$ & Z085 & ETH \\
\hline 41 & $\begin{array}{l}\text { Combretum adenogonium Steud. ex A. } \\
\text { Rich. }\end{array}$ & Combretaceae & Rukeessa & $\mathrm{T}$ & $\mathrm{Z} 212$ & ETH \\
\hline 42 & Combretum collinum Fresen. & Combretaceae & & $\mathrm{T}$ & Z080 & ETH \\
\hline 43 & Combretum molle R. Br. ex G.Don & Combertaceae & Rukeessa & $\mathrm{T}$ & Z041 & ETH \\
\hline
\end{tabular}


Tadesse et al. (2017) 4(2): 335-350

\begin{tabular}{|c|c|c|c|c|c|c|}
\hline 44 & $\begin{array}{l}\text { Combretum nigrican Lepr. ex Guill. \& } \\
\text { Perr. }\end{array}$ & Combretaceae & & $\mathrm{T}$ & Z055 & ETH \\
\hline 45 & Combretum paniculatum Vent. & Combretaceae & Hidda baggii & $\mathrm{L}$ & Z137 & ETH \\
\hline 46 & Commelina benghalensis L. & Commelinaceae & Gororaa & $\mathrm{H}$ & Z168 & ETH \\
\hline 47 & Cordia africana $\mathrm{L}$. & Boraginaceae & Waddeessa & $\mathrm{T}$ & Z114 & ETH \\
\hline 48 & $\begin{array}{l}\text { Crassocephalum macropappum } \\
\text { (Sch.Bip.ex A. Rich) S. Moore }\end{array}$ & Asteraceae & & $\mathrm{H}$ & $\mathrm{Z} 170$ & ETH \\
\hline 49 & $\begin{array}{l}\text { Crassocephalum x picridifolium ( DC) S. } \\
\text { Moore }\end{array}$ & Asteraceae & & $\mathrm{H}$ & Z169 & ETH \\
\hline 50 & Crassula alata (Viv.) Berger & Crassulaceae & & $\mathrm{H}$ & Z145 & ETH \\
\hline 51 & Crepis rueppelli Sch. Bip. & Asteraceae & & $\mathrm{H}$ & Z136 & ETH \\
\hline 52 & Crotalaria pallida Ait. & Fabaceae & & $\mathrm{H}$ & $\mathrm{Z} 200$ & ETH \\
\hline 53 & Crotalaria quartiniana A. Rich. & Fabaceae & & $\mathrm{H}$ & Z132 & ETH \\
\hline 54 & $\begin{array}{l}\text { Crotalaria rosenii (Pax) Milne-Redh.ex } \\
\text { Polhill }\end{array}$ & Fabaceae & & $\mathrm{S}$ & Z123 & ETH \\
\hline 55 & Croton macrostachyus Del. & Euphorbiaceae & Bakkanniissa & $\mathrm{T}$ & $\mathrm{Z} 030$ & ETH \\
\hline 56 & Cucumis dipsaceus Ehrenb. ex Spach & Cucurbitaceae & & $\mathrm{H}$ & Z113 & ETH \\
\hline 57 & Cyathula polycephala Bale. & Amaranthaceae & & $\mathrm{H}$ & $\mathrm{Z} 135$ & ETH \\
\hline 58 & Cymbopogon commutatus (Steud.) Stapf & Poaceae & Jajjaba & $\mathrm{H}$ & Z101 & ETH \\
\hline 59 & Cynodon dactylon (L.) Pers. & Poaceae & Coqorsa & $\mathrm{H}$ & Z103 & ETH \\
\hline 60 & Cynodon nlemfuensis Vanderyst & Poaceae & Waratii & $\mathrm{H}$ & $\mathrm{Z} 207$ & ETH \\
\hline 61 & $\begin{array}{l}\text { Cyperus sesquiflorus (Torr.) Mattf. \& } \\
\text { KUk. }\end{array}$ & Cyperaceae & Qeexamaa & $\mathrm{H}$ & $\mathrm{Z} 052$ & ETH \\
\hline 62 & Dalbergia lactea Vatke & Fabaceae & Sarxee & $\mathrm{T}$ & Z107 & ETH \\
\hline 63 & Desmodium repandum (Vahl) DC. & Fabaceae & & $\mathrm{H}$ & $\mathrm{Z} 213$ & ETH \\
\hline 64 & Diaphananthe candida Cribb & Orchidaceae & Digaluu & $\mathrm{H}$ & Z062 & ETH \\
\hline 65 & Dicranopteris linearis (Burm.f.) Underw. & Gleicheniaceae & Fern & $\mathrm{H}$ & Z034 & ETH \\
\hline 66 & $\begin{array}{l}\text { Dioscorea schimperiana } \text { Hochst. ex } \\
\text { Kunth }\end{array}$ & Dioscoreaceae & & $\mathrm{H}$ & Z047 & ETH \\
\hline 67 & Diospyros abyssinica (Hiern) F. White & Ebenaceae & Ilkee & $\mathrm{T}$ & Z089 & ETH \\
\hline 68 & Dodonaea angustifolia $\mathrm{L} . \mathrm{f}$. & Sapindaceae & Ittacha & $\mathrm{S}$ & Z088 & ETH \\
\hline 69 & Dombeya torrida (G.F. Gmel.) P. Bamps & Sterculiaceae & Daannisa & $\mathrm{T}$ & Z116 & ETH \\
\hline 70 & Dovyalis abyssinica (A. Rich.) Warb. & Flacourtiaceae & Koshommii & $\mathrm{T}$ & Z045 & ETH \\
\hline 71 & Dracaena steudneri Engl. & Dracaenaceae & Meerqoo & $\mathrm{S}$ & $\mathrm{Z} 150$ & ETH \\
\hline 72 & Drimia altissima (L.f.) Ker-Gawl. & Hycinthaceae & $\begin{array}{l}\text { Qullubbii } \\
\text { waraabessaa }\end{array}$ & $\mathrm{H}$ & Z209 & ETH \\
\hline 73 & Echinops longisetus A. Rich. & Asteraceae & Qoraattii harree & $\mathrm{S}$ & Z058 & ETH \\
\hline 74 & Ehretia cymosa Thonn. & Boraginaceae & Ulaagaa & $\mathrm{T}$ & Z021 & ETH \\
\hline 75 & Ekebergia capensis Sparrm. & Meliaceae & Somboo & $\mathrm{T}$ & Z095 & ETH \\
\hline 76 & $\begin{array}{l}\text { Englerina woodfordioides (Schweinf.)M. } \\
\text { Gilbert }\end{array}$ & Loranthaceae & Digaluu & $\mathrm{S}$ & Z119 & ETH \\
\hline 77 & Entada abyssinica Steud. ex A. Rich. & Fabaceae & Ambaltaa & $\mathrm{T}$ & Z196 & ETH \\
\hline 78 & Erythrococca abyssinica $\mathrm{Pax}$ & Euphorbiaceae & Geelloo & $\mathrm{S}$ & Z067 & ETH \\
\hline 79 & Eucalyptus camaldulensis Dehnh. & Myrtaceae & $\begin{array}{l}\text { Baargamoo } \\
\text { diimaa }\end{array}$ & $\mathrm{T}$ & Z068 & ETH \\
\hline 80 & Euclea divinorum Hiern & Ebenaceae & Mi'eessaa & $\mathrm{T}$ & Z038 & ETH \\
\hline 81 & Euphorbia schimperiana Scheele & Euphorbiaceae & & $\mathrm{S}$ & Z011 & ETH \\
\hline 82 & Ficus mucuso Ficalho. & Moraceae & Qilinxoo & $\mathrm{T}$ & Z141 & ETH \\
\hline 83 & Ficus salicifolia A. Rich. & Moraceae & Qilinxoo & $\mathrm{T}$ & Z167 & ETH \\
\hline 84 & Ficus sur Forssk. & Moraceae & Harbuu & $\mathrm{T}$ & Z164 & ETH \\
\hline 85 & Ficus sycomorus L. & Moraceae & Odaa & $\mathrm{T}$ & Z130 & ETH \\
\hline 86 & Ficus thonningii Blume & Moraceae & Dambii & $\mathrm{T}$ & Z128 & ETH \\
\hline
\end{tabular}


Tadesse et al. (2017) 4(2): 335-350

\begin{tabular}{|c|c|c|c|c|c|c|}
\hline 87 & Ficus vasta Forssk. & Moraceae & Qilxuu & $\mathrm{T}$ & Z122 & ETH \\
\hline 88 & Flacourtia indica (Burm.f.) Merr & Flacourtaceae & Akuukkuu & $\mathrm{T}$ & Z066 & ETH \\
\hline 89 & Galiniera saxifraga (Hochst.) Bridson & Rubiaceae & & $\mathrm{T}$ & $\mathrm{Z} 040$ & ETH \\
\hline 90 & Gardenia ternifolia Schumach. \&Thonn. & Rubiaceae & Gambeela & $\mathrm{T}$ & Z033 & ETH \\
\hline 91 & Geranium arabicum Forssk. & Geraniaceae & & $\mathrm{H}$ & $\mathrm{Z} 070$ & ETH \\
\hline 92 & Girardinia diversifolia (Link) Friis & Urticaceae & Doobbii & $\mathrm{H}$ & Z124 & ETH \\
\hline 93 & Glycine wightii (Wight\& Am.) Verdc. & Fabaceae & & $\mathrm{H}$ & $\mathrm{Z} 115$ & ETH \\
\hline 94 & Gnidia glauca (Fresen.) Gilg & Thymelaeaceae & Qaqaroo & $\mathrm{S}$ & $\mathrm{Z} 175$ & ETH \\
\hline 95 & Gouania longispicata Engl. & Rhamnaceae & & $\mathrm{L}$ & Z195 & ETH \\
\hline 96 & Grewia ferruginea Hochst.ex A. Rich. & Tiliaceae & Dhoqonuu & $\mathrm{T}$ & Z056 & ETH \\
\hline 97 & Guizotia schimperi Sch. Bip. ex Walp. & Asteraceae & Tuufoo & $\mathrm{H}$ & Z069 & ETH \\
\hline 98 & $\begin{array}{l}\text { Helinus mystacinus (Ait.) E. Mey. ex } \\
\text { Steud. }\end{array}$ & Rhamnaceae & $\begin{array}{l}\text { Hidda } \\
\text { hoomachoo }\end{array}$ & $\mathrm{L}$ & $\mathrm{Z} 050$ & ETH \\
\hline 99 & Heliotropium zeylanicum (Burm f.) Lam. & Boraginaceae & Maxxannee & $\mathrm{H}$ & Z029 & ETH \\
\hline 100 & $\begin{array}{l}\text { Hygrophila schulli (Hamilt.) M.R. \& } \\
\text { S.M Almeida }\end{array}$ & Acanthaceae & Qoraatii saree & $\mathrm{H}$ & Z096 & ETH \\
\hline 101 & $\begin{array}{l}\text { Hymenodictyon floribundum (Hochst. \& } \\
\text { Steud.) Robinson }\end{array}$ & Rubiaceae & Gaarrii & $\mathrm{T}$ & Z154 & ETH \\
\hline 102 & $\begin{array}{l}\text { Hyparrhenia anthistirioides (Hochst. ex } \\
\text { A. Rich) Stapf }\end{array}$ & Poaceae & Sanbaleeta & $\mathrm{H}$ & Z090 & ETH \\
\hline 103 & Hypericum quartinianum A. Rich. & Guttiferae & Hinnee & $\mathrm{T}$ & $\mathrm{Z} 181$ & ETH \\
\hline 104 & Hypoestes aristata (Vahl) Nees & Acanthaceae & Darguu & $\mathrm{H}$ & Z092 & ETH \\
\hline 105 & Ilex mitis (L.) Radlk. & Aquifoliaceae & & $\mathrm{T}$ & Z206 & ETH \\
\hline 106 & Ipomoea plebeia Meeuse & Convolvulaceae & & $\mathrm{H}$ & Z081 & ETH \\
\hline 107 & Justicia ladanoides Lam. & Acanthaceae & & $\mathrm{H}$ & Z083 & ETH \\
\hline 108 & $\begin{array}{l}\text { Justicia schimperiana (Hochst. ex Nees) } \\
\text { T. Anders. }\end{array}$ & Acanthaceae & Dhummuugaa & $\mathrm{S}$ & $\mathrm{Z} 171$ & ETH \\
\hline 109 & Kalanchoe marmorata Bak. & Crassulaceae & Bosoqqee & $\mathrm{H}$ & $\mathrm{Z} 048$ & ETH \\
\hline 110 & Laggera crispata (Vahl) Hepper \& Wood & Asteraceae & & $\mathrm{H}$ & Z189 & ETH \\
\hline 111 & Landolphia buchananii (Hall.f.) Stapf & Apocynaceae & Hidda geeboo & $\mathrm{L}$ & Z208 & ETH \\
\hline 112 & Lantana trifolia $\mathrm{L}$. & Verbenaceae & & $\mathrm{S}$ & Z198 & ETH \\
\hline 113 & Leonotis ocymifolia (Burm. f.) Iwarsson & Lamiaceae & & $\mathrm{S}$ & $\mathrm{Z} 211$ & ETH \\
\hline 114 & Lippia abyssinica (Otto \& Dietr.) & Verbenaceae & & $\mathrm{S}$ & $\mathrm{Z} 078$ & ETH \\
\hline 115 & Lippia adoensis Hochst. ex Walp & Verbenaceae & Kusaayee & $\mathrm{S}$ & Z006 & ETH \\
\hline 116 & Loudetia flavida (Stapf) C. E. Hubb. & Poaceae & & $\mathrm{H}$ & Z043 & ETH \\
\hline 117 & Maesa lanceolata Forssk. & Myrsinaceae & Abbayyii & $\mathrm{T}$ & Z059 & ETH \\
\hline 118 & Malva verticillata $\mathrm{L}$. & Malvaceae & Hincinnii & $\mathrm{H}$ & $\mathrm{Z} 044$ & ETH \\
\hline 119 & Maytenus arbutifolia (A.Rich.) Wilczek & Celastraceae & Kombolcha & $\mathrm{S}$ & $\mathrm{Z} 007$ & ETH \\
\hline 120 & $\begin{array}{l}\text { Maytenus gracilipes (Welw. ex Oliv.) } \\
\text { Exell }\end{array}$ & Celastraceae & Acaacii & $\mathrm{S}$ & $\mathrm{Z100}$ & ETH \\
\hline 121 & Maytenus obscura (A. Rich.) Cuf. & Celastraceae & Kombolcha & $\mathrm{S}$ & Z073 & ETH \\
\hline 122 & Medicago polymorpha $\mathrm{L}$. & Fabaceae & Siddisa & $\mathrm{H}$ & Z074 & ETH \\
\hline 123 & Microglossa pyrifolia (Lam.) 0. Kuntze & Asteraceae & & $\mathrm{S}$ & $\mathrm{Z} 110$ & ETH \\
\hline 124 & $\begin{array}{l}\text { Mikaniopsis clematoides (Sch. Bip. ex A. } \\
\text { Rich.) Milne-Redh. }\end{array}$ & Asteraceae & & $\mathrm{H}$ & Z091 & ETH \\
\hline 125 & Millettia ferruginea (Hochst.) Bak. & Fabaceae & Sootalloo & $\mathrm{T}$ & $\mathrm{Z} 117$ & ETH \\
\hline 126 & Mimosa pigra $\mathrm{L}$. & Fabaceae & Arangamaa & $\mathrm{S}$ & $\mathrm{Z} 214$ & ETH \\
\hline 127 & Mimusops kummel A. DC. & Sapotaceae & Qolaatii & $\mathrm{T}$ & $\mathrm{Z} 140$ & ETH \\
\hline 128 & Monechma debile (Forssk.) Nees & Acanthaceae & & $\mathrm{H}$ & Z028 & ETH \\
\hline 129 & Myrsine africana $\mathrm{L}$. & Myrsinaceae & Qacama & $\mathrm{S}$ & Z065 & ETH \\
\hline 130 & Nuxia congesta R.Br. ex Fresen. & Loganiaceae & Qawwisa & $\mathrm{T}$ & Z194 & ETH \\
\hline
\end{tabular}


Tadesse et al. (2017) 4(2): 335-350

\begin{tabular}{|c|c|c|c|c|c|c|}
\hline 131 & Ocimum lamiifolium Hochst. ex. Benth. & Lamiaceae & Ancabbii diimaa & $\mathrm{S}$ & Z014 & ETH \\
\hline 132 & Ocimum urticifolium Roth. & Lamiaceae & Ancabbii adii & $\mathrm{S}$ & Z084 & ETH \\
\hline 133 & $\begin{array}{l}\text { Olea capensis L. subsp. macrocarpa } \\
\text { (C.H. Wright) Verdc. }\end{array}$ & Oleaceae & Gagamaa & $\mathrm{T}$ & Z147 & ETH \\
\hline 134 & $\begin{array}{l}\text { Olea europaea L. subsp. cuspidata } \\
\text { (Wall.ex G.Don) Cif. }\end{array}$ & Oleaceae & Ejersa & $\mathrm{T}$ & Z097 & ETH \\
\hline 135 & Olinia rochetiana A.Juss. & Oliniaceae & Daalachoo & $\mathrm{T}$ & $\mathrm{Z} 025$ & ETH \\
\hline 136 & Ophrestia radicosa (A. Rich.) Verde. & Fabaceae & Hidda bofaa & $\mathrm{H}$ & Z017 & ETH \\
\hline 137 & Oplismenus hirtellus (L.) P. Beauv. & Poaceae & Ashuffee & $\mathrm{H}$ & Z053 & ETH \\
\hline 138 & Oreosyce africana Hook.f. & Cucurbitaceae & & $\mathrm{H}$ & Z186 & ETH \\
\hline 139 & Osyris quadripartita Decne & Santalaceae & Waatoo & $\mathrm{T}$ & Z026 & ETH \\
\hline 140 & Panicum monticola Hook.f. & Poaceae & Marga gogorrii & $\mathrm{H}$ & Z105 & ETH \\
\hline 141 & Pavetta abyssicica Fresen. & Rubiaceae & & $\mathrm{S}$ & Z024 & ETH \\
\hline 142 & Pellaea calomelanos (Sw.) Link & Sinopteridaceae & & $\mathrm{H}$ & Z071 & ETH \\
\hline 143 & Pennisetum thunbergii Kunth & Poaceae & Migira saree & $\mathrm{H}$ & Z102 & ETH \\
\hline 144 & $\begin{array}{l}\text { Periploca llnearlfolia Quart.-Dill. \& A. } \\
\text { Rich. }\end{array}$ & Asclepiadaceae & Hidda aannannoo & $\mathrm{L}$ & $\mathrm{Z160}$ & ETH \\
\hline 145 & Phaulopsis imbricata (Forssk.) Sweet & Acanthaceae & & $\mathrm{H}$ & Z049 & ETH \\
\hline 146 & Phoenix reclinata Jacq. & Arecaceae & Meexxii & $\mathrm{T}$ & Z129 & ETH \\
\hline 147 & Phyllanthus mooneyi M. Gilbert & Euphorbiaceae & & $\mathrm{S}$ & $\mathrm{Z} 187$ & ETH \\
\hline 148 & Phyllanthus ovalifolius Forssk. & Euphorbiaceae & Qacamoo & $\mathrm{T}$ & Z104 & ETH \\
\hline 149 & $\begin{array}{l}\text { Phymatosorus scolopendria (Burn.f.) } \\
\text { Pic. Serm }\end{array}$ & Polypodiaceae & & $\mathrm{H}$ & $\mathrm{Z} 184$ & ETH \\
\hline 150 & Phytolacca dodecandra L'Herit. & Phytolaccaceae & Andoodee & $\mathrm{S}$ & $\mathrm{Z} 148$ & ETH \\
\hline 151 & Pittosporum viridiflorum Sims & Pittosporaceae & Soolee adii & $\mathrm{T}$ & $\mathrm{Z} 210$ & ETH \\
\hline 152 & Plectranthus punctatus (L.f.) L'H'er. & Lamiaceae & & $\mathrm{H}$ & $\mathrm{Z} 205$ & ETH \\
\hline 153 & $\begin{array}{l}\text { Pliostigma thonningii (Schumach.) } \\
\text { Milne-Redh }\end{array}$ & Fabaceae & & $\mathrm{T}$ & $\mathrm{Z} 127$ & ETH \\
\hline 154 & $\begin{array}{l}\text { Podocarpus falcatus (Thunb.) R.B. ex. } \\
\text { Mirb. }\end{array}$ & Podocarpaceae & Birbirsa & $\mathrm{T}$ & Z098 & ETH \\
\hline 155 & $\begin{array}{l}\text { Polypogon schimperianus (Hochst. ex } \\
\text { Steud.) Cope }\end{array}$ & Poaceae & Daggala & $\mathrm{H}$ & $\mathrm{Z} 042$ & ETH \\
\hline 156 & Premna schimperi Engl. & Lamiaceae & Urgeessaa & $\mathrm{S}$ & Z009 & ETH \\
\hline 157 & Prunus africana (Hook.f.) Kalkm. & Rosaceae & Hoomii & $\mathrm{T}$ & $\mathrm{Z} 203$ & ETH \\
\hline 158 & $\begin{array}{l}\text { Pseudognaphalium luteo-album (L.) } \\
\text { Hilliard \& Burtt }\end{array}$ & Asteraceae & & $\mathrm{H}$ & Z022 & ETH \\
\hline 159 & Psychotria orophila Petit & Rubiaceae & & $\mathrm{S}$ & Z099 & ETH \\
\hline 160 & Pterolobium stellantum (Forssk.) Brenan & Fabaceae & Arangamaa & $\mathrm{L}$ & Z138 & ETH \\
\hline 161 & Pycnostachys abyssinica Fresen. & Lamiaceae & Bokkolluu & $\mathrm{H}$ & $\mathrm{Z} 121$ & ETH \\
\hline 162 & Rhamnus prinoides L'Herit. & Rhamnaceae & Geeshoo & $\mathrm{S}$ & Z087 & ETH \\
\hline 163 & Rhamnus staddo A.Rich. & Rhamnaceae & Qadiidaa & $\mathrm{T}$ & Z093 & ETH \\
\hline 164 & Rhoicissus revoilii Planch. & Rhamnaceae & Indirifaa & $\mathrm{L}$ & Z061 & ETH \\
\hline 165 & Rhus natalensis Krauss & Anacardiaceae & Xaaxessaa & $\mathrm{T}$ & Z019 & ETH \\
\hline 166 & Rhus vulgaris Meikle & Anacardiaceae & Xaaxessaa & $\mathrm{T}$ & Z002 & ETH \\
\hline 167 & Ricinus communis $\mathrm{L}$. & Euphorbiaceae & Qobboo & $\mathrm{S}$ & $\mathrm{Z} 202$ & ETH \\
\hline 168 & Rosa abyssinica Lindley & Rosaceae & Qaqawwii & $\mathrm{S}$ & $\mathrm{Z} 060$ & ETH \\
\hline 169 & $\begin{array}{l}\text { Rothmannia urcelliformis (Hiem) } \\
\text { Robyns }\end{array}$ & Rubiaceae & Qola-gurraa & $\mathrm{T}$ & Z146 & ETH \\
\hline 170 & Rubia cordifolia $\mathrm{L}$. & Rubiaceae & Maxxannee & $\mathrm{H}$ & Z036 & ETH \\
\hline 171 & Rubus apetalus Poir. & Rosaceae & Goraa & $\mathrm{L}$ & Z201 & ETH \\
\hline 172 & Rubus steudneri Schweinf. & Rosaceae & Goraa & $\mathrm{L}$ & Z188 & ETH \\
\hline 173 & Rumex nepalensis Spreng. & Polygonaceae & Timijjii & $\mathrm{H}$ & Z191 & ETH \\
\hline
\end{tabular}


Tadesse et al. (2017) 4(2): 335-350

\begin{tabular}{|c|c|c|c|c|c|c|}
\hline 174 & Rytigynia neglecta (Hiern) Robyns & Rubiaceae & Mixoo & $\mathrm{S}$ & Z079 & ETH \\
\hline 175 & $\begin{array}{l}\text { Salix mucronata Thunb. (S. subserrata } \\
\text { Willd) }\end{array}$ & Salicaceae & Alaltuu & $\mathrm{T}$ & Z193 & ETH \\
\hline 176 & Sapium ellipticum (Krauss) Pax. & Euphorbiaceae & Bosoqa & $\mathrm{T}$ & Z139 & ETH \\
\hline 177 & Satureja abyssinica (Benth.) Briq. & Lamiaceae & & $\mathrm{H}$ & $\mathrm{Z} 174$ & ETH \\
\hline 178 & Satureja punctata (Benth.) Briq. & Lamiaceae & & $\mathrm{S}$ & Z106 & ETH \\
\hline 179 & $\begin{array}{l}\text { Schefflera abyssinica (Hochst. ex A. } \\
\text { Rich.) Harms }\end{array}$ & Araliaceae & Gatamaa & $\mathrm{T}$ & Z086 & ETH \\
\hline 180 & Schrebera alata (Hochst.) Welw. & Oleaceae & Qana'ee & $\mathrm{T}$ & Z004 & ETH \\
\hline 181 & Scutia myrtina (Burm. f.) Kurz & Rhamnaceae & Kombolcha adii & $\mathrm{S}$ & Z111 & ETH \\
\hline 182 & Senna petersiana (Bolle) Lock & Fabaceae & Gaafatoo & $\mathrm{T}$ & $\mathrm{Z} 072$ & ETH \\
\hline 183 & $\begin{array}{l}\text { Senna septemtrionalis (Viv.) Irwin \& } \\
\text { Bameby }\end{array}$ & Fabaceae & & $\mathrm{S}$ & Z190 & ETH \\
\hline 184 & $\begin{array}{l}\text { Setaria megapbylla (Steud.) Th. Dur. \& } \\
\text { Schinz }\end{array}$ & Poaceae & Jajjaba & $\mathrm{H}$ & Z054 & ETH \\
\hline 185 & Sida ternata L.f. & Malvaceae & Hincinnii & $\mathrm{H}$ & Z082 & ETH \\
\hline 186 & Sida rhombifolia L. & Malvaceae & Karabaa & $\mathrm{S}$ & Z156 & ETH \\
\hline 187 & Sida schimperiana Hochst. ex A. Rich. & Malvaceae & Cirfiggii & $\mathrm{S}$ & Z012 & ETH \\
\hline 188 & Sida urens L. & Malvaceae & Hincinnii & $\mathrm{S}$ & Z035 & ETH \\
\hline 189 & Solanum aculeatissimum Jacq. & Solanaceae & $\begin{array}{l}\text { Hiddii } \\
\text { waraabessaa }\end{array}$ & $\mathrm{S}$ & $\mathrm{Z} 037$ & ETH \\
\hline 190 & Solanum anguivi Lam. & Solanaceae & Hiddii saree & $\mathrm{S}$ & Z133 & ETH \\
\hline 191 & Solanum giganteum Jacq. & Solanaceae & & $\mathrm{S}$ & Z046 & ETH \\
\hline 192 & Solanum macracanthum A. Rich. & Solanaceae & Hiddii & $\mathrm{S}$ & Z015 & ETH \\
\hline 193 & Solanum marginatum L.f. & Solanaceae & Hiddii hongorcaa & $\mathrm{S}$ & $\mathrm{Z} 155$ & ETH \\
\hline 194 & Sphaerantuhs suaveolens (Forssk) DC. & Asteraceae & Bokkolluu & $\mathrm{H}$ & Z112 & ETH \\
\hline 195 & $\begin{array}{l}\text { Sporobolus africanus (Poir.) Robyns \& } \\
\text { Tourny }\end{array}$ & Poaceae & Murii & $\mathrm{H}$ & $\mathrm{Z} 010$ & ETH \\
\hline 196 & Stereospermum kunthianum Cham. & Bignoniaceae & Botoroo & $\mathrm{T}$ & $\mathrm{Z} 077$ & ETH \\
\hline 197 & Syzygium guineense (Willd.) DC. & Myrtaceae & Baddeessaa & $\mathrm{T}$ & $\mathrm{Z} 076$ & ETH \\
\hline 198 & Tagetes minuta $\mathrm{L}$. & Asteraceae & & $\mathrm{H}$ & Z032 & ETH \\
\hline 199 & $\begin{array}{l}\text { Tapinanthus heteromorphus (A. Rich.] } \\
\text { Danser }\end{array}$ & Loranthaceae & Digaluu & $\mathrm{S}$ & Z057 & ETH \\
\hline 200 & Teclea nobilis Del. & Rutaceae & Hadheessa & $\mathrm{T}$ & Z159 & ETH \\
\hline 201 & Teramnus labialis (L. f.) Spreng. & Fabaceae & & $\mathrm{H}$ & Z158 & ETH \\
\hline 202 & Terminalia macroptera Guill \& Perr. & Combretaceae & Dabaqqaa & $\mathrm{T}$ & Z161 & ETH \\
\hline 203 & Terminalia schimperiana Hochst. & Combretaceae & Gaarrii & $\mathrm{T}$ & Z126 & ETH \\
\hline 204 & $\begin{array}{l}\text { Thalictrum rhynchocarpum Dill. \& } \\
\text { A.Rich. }\end{array}$ & Ranunculaceae & Sire bizuu & $\mathrm{H}$ & Z163 & ETH \\
\hline 205 & Thunbergia alata Boj. ex Sims & Convolvulaceae & & $\mathrm{H}$ & $\mathrm{Z} 143$ & ETH \\
\hline 206 & Tragia ashiae M.Gilbert & Euphorbiaceae & Gurgubbee & $\mathrm{H}$ & Z039 & ETH \\
\hline 207 & Tragia brevipes $\mathrm{Pax}$ & Euphorbiaceae & Gurgubbee & $\mathrm{H}$ & Z031 & ETH \\
\hline 208 & Urera hypselodendron (A.Rich,) Wedd. & Urticaceae & Laanqisaa & $\mathrm{L}$ & $\mathrm{Z} 172$ & ETH \\
\hline 209 & Vangueria apiculata K. Schum. & Rubiaceae & Buruurii & $\mathrm{S}$ & Z064 & ETH \\
\hline 210 & Vernonia amygdalina Del. & Asteraceae & Eebicha & $\mathrm{T}$ & Z177 & ETH \\
\hline 211 & Vernonia hochstetteri Sch.Bip. ex Walp. & Asteraceae & Sooyyoma & $\mathrm{S}$ & $\mathrm{Z} 173$ & ETH \\
\hline 212 & Vernonia hymenolepis A. Rich. & Asteraceae & Sooyyoma & $\mathrm{S}$ & $\mathrm{Z} 180$ & ETH \\
\hline 213 & $\begin{array}{l}\text { Vernonia leopoldi (Sch. Bip. ex Walp.) } \\
\text { Vatke }\end{array}$ & Asteraceae & & $\mathrm{S}$ & Z109 & ETH \\
\hline 214 & Vernonia myriantha Hook.f. & Asteraceae & Reejjii & $\mathrm{T}$ & Z134 & ETH \\
\hline
\end{tabular}

Note: $\mathrm{T}=$ Tree; $\mathrm{S}=$ Shrub; $\mathrm{L}=$ Liana; $\mathrm{H}=\mathrm{Herb}$; . code= Collection code; Ha= Habit; ETH= National Herbarium of Ethiopia. 